\title{
A anistia entre a memória e o esquecimento ${ }^{1}$
}

\author{
Amnesty between memory and oblivion
}

\footnotetext{
${ }^{1}$ Este artigo é resultado da pesquisa $A$ luta pela anistia e a resistência à Ditadura no Rio Grande do Sul, realizada na UFRCS, desde agosto de 2007. Conta com a participação dos alunos Gabriel Dienstmann (bolsista de Iniciação Científica pela Fapergs) e Tatiana Trindade (bolsista de Iniciação Científica da UFRCS). Conta também com o trabalho voluntário do(a)s seguintes estudantes de História: Meriane Flores, Maria Cláudia Moraes Leite, Denise Xavier e Márcio Blanco. Agradeço aos alunos e alunas das disciplinas de Seminário Temático de História do Brasil III e de Seminário de Cultura e Representações que, na graduação e na pós-graduação em História da UFRGS, ajudaram a refletir sobre o tema da pesquisa, ao longo do primeiro semestre de 2009. Aos debates em aula, devem-se algumas das reflexões presentes neste artigo. As fontes primárias utilizadas fazem parte do Acervo de Lícia Peres e de Mila Cauduro e foram pesquisadas no Acervo da Luta Contra a Ditadura, instituição que hoje se chama Centro da Memória Documental da Ditadura Militar no Rio Grande do Sul e que faz parte do Arquivo Histórico do Estado do Rio Grande do Sul, localizado no prédio do Memorial do Rio Grande do Sul. Ver também: Rodeghero et al. (2009).

${ }^{2}$ Doutora em História, professora do Departamento e da PósGraduação em História da UFRGS.
}

\author{
Carla Simone Rodeghero ${ }^{2}$
}

carlasr@cpovo.net

\begin{abstract}
Resumo. Este artigo discute as diferentes concepções de anistia que marcaram a atuação de militantes que empunhavam esta bandeira a partir de $1975 . \mathrm{Na}$ atuação de protagonistas como a advogada Therezinha Zerbine, a escritora Mila Cauduro e o general Peri Bevilacqua, podem ser captadas representações que associavam a anistia à reconciliação nacional, à pacificação da família brasileira, e, ainda, ao ato generoso das autoridades. Essas representações conviveram e disputaram espaço, a partir de 1978, com aquelas construídas pelos Comitês Brasileiros de Anistia espalhados pelo país, que passaram a defender uma anistia ampla, geral e irrestrita, propondo o desmonte radical da Ditadura. A análise do livro Liberdade para os brasileiros, de Roberto Ribeiro Martins, aproxima-se dessa concepção. $\mathrm{Na}$ comparação entre essas diferentes formas de dar significado à anistia, é possível perceber situações nas quais ela é associada ao esquecimento do passado; e outras, que tomam a luta pela anistia como oportunidade valiosa para trazer tal passado à tona. Nesse quadro, o artigo analisa a convivência e a disputa entre as concepções de anistia/esquecimento e as de anistia/memória. Mostra, também, como o caso da anistia se liga às polêmicas mais gerais - e ainda atuais - relacionadas ao modo como a sociedade brasileira lidou e lida com as marcas e as feridas deixadas pela Ditadura.
\end{abstract}

Palavras-chave: anistia, memória, esquecimento, Ditadura.

Abstract. This article discusses the different conceptions of amnesty which marked the engagement of militants who have fought for such ideal from 1975. The leading roles played by the lawyer Therezinha Zerbine, by the writer Mila Cauduro and by General Peri Bevilacqua can be taken as representations which associated amnesty with national reconciliation, with the "pacification of the Brazilian family", and with the generous act of the authorities. Such representations coexisted, and disputed the scenario, from 1978, with the ones built by the Brazilian Amnesty Committees spread in the country, which began to defend "a wider, more general and unrestricted amnesty", proposing the radical dismantling of dictatorship. The analysis of the book Liberdade para os brasileiros, by Roberto Ribeiro Martins, leads us to this conception. Comparing these two different ways of signifying amnesty, it is possible to notice situations in which amnesty is associated to the oblivion of the past and others which take the fight for amnesty as a valuable opportunity to bring the past back. In this scenario, the article will analyze the coexistence and the dispute between the conceptions of amnesty/oblivion and amnesty/ 
memory, showing how the amnesty case is linked to more general polemics - and still actual ones - regarding the way in which the Brazilian society dealt/deals with the wounds left by dictatorship.

Key words: amnesty, memory, oblivion, dictatorship.

Em junho de 1979, o presidente João Batista Figueiredo enviou ao Congresso Nacional o seu projeto de anistia. Tal medida é passível de ser entendida como uma das estratégias governistas para garantir uma transição segura do Regime Militar para um governo civil, dando continuidade à política da distensão inaugurada no governo de Ernesto Geisel. O envio do projeto pode ser também encarado como uma resposta à intensa pressão de setores políticos e da sociedade civil para que fosse concedida a anistia. Essa pressão vinha sendo exercida desde 1975 pelo Movimento Feminino pela Anistia (MFPA) e, a partir de 1978, pelos Comitês Brasileiros pela Anistia (CBAs), em conjunto com outras entidades organizadas ou reorganizadas naqueles anos. O Movimento Democrático Brasileiro (MDB) também levantava a bandeira da anistia.

Sabe-se que o projeto do governo foi alvo de muitas críticas, pelas suas limitações e pelo espírito de reciprocidade que o inspirava. Uma anistia que não contemplava crimes caracterizados como de terrorismo e que perdoava os chamados crimes conexos estava muito distante da tão desejada Anistia ampla, geral e irrestrita, slogan que se transformou em uma legenda da mobilização política de 1978 e de 1979. Quando o projeto foi enviado ao Congresso, os debates - travados na imprensa, nos parlamentos, nas entidades ligadas à luta de diferentes categorias de atingidos pelos atos de exceção da Ditadura - tornaram clara a oposição entre uma anistia restrita e recíproca e uma anistia ampla, geral e irrestrita. A intensidade desses debates e a vitória do projeto restritivo e recíproco do governo podem ter deixado escondidas certas divergências que existiram entre aqueles que criticavam o projeto do governo ou que, antes dele, pressionavam-no para que se manifestasse a respeito da anistia.

Por conta disso, propõe-se explorar uma camada de debate um tanto escondida ou esquecida: aquela que se refere às diferentes concepções sobre anistia que marcaram a militância de alguns protagonistas desde $1975 . \mathrm{Na}$ medida em que esses debates forem reconstituídos, virão à tona as conexões entre anistia, perdão e esquecimento e anistia, justiça e memória, temas que, ainda hoje, marcam o debate político sobre a herança da Ditadura.

\section{O projeto do governo}

O projeto do governo Figueiredo, que assumiu a Presidência da República em março de 1979, pode ser encarado como um avanço em relação à postura que marcou o final do mandato de seu antecessor, o presidente Geisel, de não mencionar o tema da anistia ou de defender a sua inviabilidade. O crescimento da mobilização pela anistia, com a criação dos CBAs, a partir de fevereiro de 1978, certamente permitiu colocar o tema "na ordem do dia"(Greco, 2003,p. 132). Quando o governo se comprometeu a enviar o projeto ao Congresso, ao mesmo tempo em que respondia às demandas de setores da oposição, tirava deles a iniciativa da proposta.

Conforme a Constituição de 1967, emendada em 1969, cabia unicamente ao Executivo a prerrogativa de enviar um projeto de anistia para apreciação do Congresso. Pelo projeto governamental, que depois se transformou em Lei, seriam anistiados aqueles indivíduos que, entre dois de setembro de $1961 \mathrm{e} 15$ de agosto de 1979 , cometeram crimes políticos ou conexos a esses, com exceção dos condenados por crimes de terrorismo, assalto, sequestro e atentado pessoal. O projeto previa, também, que o retorno dos funcionários civis ou militares ao serviço público estaria condicionado à existência de vagas e ao interesse da administração. Comissões seriam montadas nos órgãos públicos civis e nas Forças Armadas para avaliar os pedidos de reintegração. Os familiares que tinham parentes desaparecidos, há mais de um ano, poderiam requerer do governo uma declaração de ausência. Sindicalistas e empregados das empresas privadas também poderiam voltar a seus postos. Os direitos políticos dos anistiados seriam restabelecidos (Greco, 2003, p. 296-297).

Segundo afirma a historiadora Greco (2003), a lei de anistia do governo reflete a matriz na qual foi gerada a Doutrina de Segurança Nacional e está marcada pela lógica do esquecimento. Três dos seus tópicos visavam ocultar a verdade e interditar a memória. É o caso (i) da menção aos crimes conexos; (ii) da exclusão dos crimes associados ao terrorismo; e, ainda, (iii) do tratamento dado aos mortos e aos desaparecidos. A reciprocidade gerava, segundo a autora, a impunidade e a perpetuação da prática da tortura. A exclusão dos guerrilheiros reiterava o inimigo interno da Doutrina e, finalmente, a declaração de ausência dos mortos e dos desaparecidos não comportava a responsabilização do Estado por esses casos. Outra limitação da lei é que ela anistiava apenas aquelas punições que tivessem tido como fundamento os atos institucionais e complementares, descartando outros diplomas legais, com base nos quais os inimigos do Regime também foram atingidos. 


\section{A anistia como reconciliação}

A anistia caracterizada como ampla, geral e irrestrita passou a ser defendida, nesses termos, ao longo de 1978, depois da criação dos CBAs. O primeiro foi fundado em fevereiro, no Rio de Janeiro. Depois, foi a vez de São Paulo, Rio Grande do Sul, Belo Horizonte, Londrina, além de outras cidades no Brasil e no exterior. Desde 1975, no entanto, tal luta era levada adiante pelos núcleos do MFPA, por setores do MDB, da Ordem dos Advogados do Brasil (OAB) e da Igreja Católica. O MFPA foi fundado em maio de 1975, em São Paulo, pela advogada Therezinha Godoy Zerbine. No mesmo ano, surgiram os núcleos de Porto Alegre, do Rio de Janeiro, de Belo Horizonte e de Londrina (Del Porto, 2002, p. 121). O Movimento foi inaugurado com a divulgação do Manifesto da Mulher Brasileira e de uma coleta de assinaturas de mulheres que acompanharia o Manifesto a ser entregue ao Presidente da República, general Ernesto Geisel. O Manifesto tinha o seguinte conteúdo:

Nós, mulheres brasileiras, assumimos nossas responsabilidades de cidadâs no quadro político nacional. Através da história provamos o espírito solidário da mulher, fortalecendo aspirações de amor ejustiça. Eis porque nós nos antepomos aos destinos da Nação que só cumprirá sua finalidade de paz se for concedida anistia ampla e geral a todos aqueles que foram atingidos pelos atos de exceção. Conclamamos todas as mulheres no sentido de se unirem a esse movimento, procurando o apoio de todos que se identifiquem com a ideia da necessidade de anistia, tendo em vista um dos objetivos nacionais: a união da Nação (Zerbine, 1979, p. 27).

Como se vê, o Manifesto apelava para as responsabilidades femininas frente à política. A mobilização do espírito solidário das mulheres permitiria alcançar a paz, especificamente, por intermédio de uma medida jurídica, a anistia. Essa anistia é caracterizada como ampla e geral. Com ela, seria possível alcançar a união do Brasil, entendida como "um dos objetivos nacionais" (Zerbine, 1979, p. 27). Nessas poucas sentenças que compõem o Manifesto, é possível vislumbrar uma concepção de Nação que, de alguma forma, dialoga com a Doutrina de Segurança Nacional, na medida em que se refere aos "destinos da Nação" e, também, aos "objetivos nacionais" (Zerbine, 1979, p. 27). As duas expressões pressupõem o desejo de uma Nação que, unida e conciliada, caminhasse para o futuro. Tal futuro, no entanto, se mostrava incerto. Seria preciso que as mulheres se antecipassem a ele e, como cidadãs, dessem sua colaboração na conquista da paz, encampando a bandeira da anistia "a todos aqueles que foram atingidos por atos de exceção"(Zerbine, 1979, p. 27).
Desde a criação do primeiro núcleo do MFPA, Therezinha Zerbine foi incansável na divulgação da causa (Zerbine, 1979). Participou do Congresso Mundial das Mulheres, no México, viajou para diversas partes do Brasil, acompanhando e incentivando a formação de novos núcleos, e concedeu inúmeras entrevistas. Os discursos pronunciados nessas ocasiões permitem que se acompanhem as permanências e as transformações na forma como a advogada e o Movimento que ela liderava caracterizavam a tão desejada anistia. Entre os temas que são mais recorrentes nas falas de Therezinha Zerbine, nos primeiros anos de atuação do MFPA, estão o da anistia como reconciliação da família brasileira, o da tradição de anistias presente na história do Brasil, e o do papel das mulheres na sociedade. Como os três temas aparecem interligados, inicia-se a discussão pelo último.

Dos relatos que Therezinha Zerbine fez, repetidas vezes, sobre sua estada no México, em junho de 1975, temse a impressão que, durante o Congresso promovido pela ONU, a advogada teve um primeiro e impactante contato com o movimento feminista, o qual foi avaliado de forma negativa pela brasileira: "[...] na Europa e nos Estados Unidos, pude notar nitidamente problemas e colocações de uma sociedade velha, decadente, com problemas como lesbianismo, prostituição, aborto etc., que não deixam de ser problemas, mas não tão fundamentais" (Zerbine, 1979 , p. 31). Ao mesmo tempo em que avaliava as demandas das mulheres do Primeiro Mundo, denunciava que, no Brasil, se tentava seguir as feministas inglesas e norte-americanas, e que com isso, ficavam esquecidos os problemas que realmente importavam para a realidade latino-americana como a garantia de pão, teto, educação, saúde etc. (Zerbine, 1979, p. 22).

Essa recusa, por parte de Therezinha Zerbine, de conferir legitimidade aos problemas apresentados pelas mulheres que se identificavam com o feminismo foi contemporânea do surgimento de entidades que, no Brasil, se assumiam como feministas (Sohiet e Esteves, 2007; Pedro, 2006). Identificando-se como feminino, o MFPA pautou seu discurso pela defesa da família, entendendo o país como uma grande família, a qual se encontrava dividida pelas discordâncias políticas, bipartida em vencedores e em vencidos. Às mulheres cabia a iniciativa para sensibilizar as autoridades a respeito da necessidade da anistia. Esta anistia é caracterizada como ampla e geral, no sentido de abranger "todos os atingidos por atos de exceção", como se lê no Manifesto de 1975 (Zerbine, 1979, p. 27). Indicavam-se todos os atingidos e não apenas parte deles.

Ao mesmo tempo, Therezinha Zerbine (1979) mobilizava o argumento de que o Brasil tinha uma tradição de anistias. Olhando para o passado, poderiam ser encontra- 
dos os exemplos de situações nas quais, após conflagrações e violências políticas, autoridades sábias tinham decretado a anistia e garantido a pacificação e a reconciliação dos brasileiros. Um dos exemplos frequentemente citados é o das anistias e pacificações promovidas por Duque de $\mathrm{Ca}^{-}$ xias, durante o Período Imperial. Getúlio Vargas também é lembrado como um grande pacificador.

A concepção de anistia como pacificação ou reconciliação da família brasileira tem como pressuposto a crença na possibilidade e na positividade do esquecimento daquilo que, no passado, gerou confronto e violência. Isso aproxima o discurso do MFPA da doutrina jurídica construída e consolidada sobre anistia no Brasil, especialmente, a partir dos escritos de Rui Barbosa, para quem anistia significava esquecimento, "desmemória plena"(Barbosa in Martins, 1978, p. 57). Essa relação íntima entre anistia e esquecimento continua presente em interpretações jurídicas até nossos dias. Evandro Lins e Silva, que foi jurista e membro da Academia Brasileira de Letras, falecido em 2002, redigiu o verbete "Anistia" para o Dicionário Histórico Biográfico Brasileiro (DHBB), publicado em segunda edição em 2001, pela Fundação Getúlio Vargas. Para Lins e Silva, "anistiar representa o esquecimento do fato ou fatos que trouxeram a perturbação da ordem vigente, é o oblívio, é apagar da lembrança o acontecimento violador da lei penal" (Lins e Silva, 2001, vol. 1, p. 255).

No quesito esquecimento, a concepção de anistia, captada nos escritos dos primeiros anos de militância de Therezinha Zerbine, se aproxima da doutrina jurídica hegemônica. No entanto, há limites nessa aproximação. O Manifesto da Mulher Brasileira (Zerbine, 1979, p. 27) fala de anistia a "todos os atingidos por atos de exceção" e não de anistia aos que "trouxeram perturbação da ordem vigente", ou anistia "aos que cometeram crimes políticos”. Esta última fórmula está presente em boa parte das leis ou decretos de anistias que o Brasil teve (Martins, 1978). Caracterizar os beneficiários da anistia como aqueles que foram "atingidos por atos de exceção" (Zerbine, 1979, p. 27), reforça a excepcionalidade e, por que não, a justeza dos atos dessas pessoas que, apenas pela existência de uma legislação de exceção, foram consideradas criminosas.

Uma das principais lideranças do núcleo gaúcho do MFPA, a escritora Mila Cauduro, compartilhava das concepções de anistia de Therezinha Zerbine. Quando assumiu a presidência do Núcleo, em 1976, Mila Cauduro encaminhou correspondência a diversas autoridades - deputados estaduais, arcebispo de Porto Alegre, lideranças do $\mathrm{MDB}$, presidente da $\mathrm{OAB}$ etc., se apresentando e pedindo apoio à continuidade da luta em favor da anistia. A leitura das minutas das cartas enviadas permite identificar uma espécie de modelo de redação, que assim se referia à anistia: "anistia ampla - ato que virá a pacificar a família brasileira, reintegrando, assim, centenas de ilustres patrícios nossos no processo político nacional" (Cauduro, 1976a), ou "anistia ampla - ato de grandeza que nunca esteve ausente de nossa história" (Cauduro, 1976b), ou, ainda, "movimento em prol de um ato que virá a pacificar a família brasileira, reintegrar centenas de cidadãos ilustres no processo político nacional" (Cauduro, 1976c). Nestas expressões, assim como se viu nos pronunciamentos de Therezinha Zerbine, destaca-se a ideia do Brasil como uma família e menciona-se a tradição das anistias que marcou a história brasileira. É reforçada, ainda, a associação entre anistia e exilados, sendo estes agora classificados como ilustres patrícios ou cidadãos. Essa associação pode ser considerada uma marca importante da atuação do MFPA gaúcho que, entre suas militantes, contava com mulheres que tinham relações (políticas e familiares) muito próximas com líderes trabalhistas no exílio.

\section{A anistia recíproca}

A campanha pela anistia no Rio Grande do Sul serve de ponte para a introdução de mais um protagonista de peso nessa luta, e mais um conjunto de percepções a respeito da anistia. Entre março e abril de 1978, surgiu o Comitê Unitário pela Anistia do Rio Grande do Sul. Mais adiante, ele se transformou no núcleo gaúcho do CBA. Em 29 de março, aconteceu, na Assembleia Legislativa, o Dia Nacional de Protesto em memória aos dez anos da morte de Edson Luís (MFPA-RS, 1978). Posterior a isso, começou a ser montado o Comitê Unitário. As entidades promotoras distribuíram um manifesto à imprensa e marcaram para 11 de abril o lançamento do Comitê, mediante um abaixo - assinado, em frente à Prefeitura Municipal de Porto Alegre. Convidado pelo MFPA-RS, no dia seguinte, na Assembleia Legislativa, o general cassado Peri Bevilacqua proferiu uma palestra. A partir do texto da palestra, arquivado pelas militantes do MFPA, pode-se ter acesso a outra concepção de anistia que, em alguns pontos, se aproxima e, em outros, se afasta daquelas acima apresentadas.

Nos anos iniciais da Ditadura, Peri Bevilacqua fazia parte do Superior Tribunal Militar (STM) e vinha demonstrando descontentamento em relação às ondas de punições que se seguiram ao primeiro e ao segundo Atos Institucionais (AIs) (Abreu et al., 2001).Já em 1966, em entrevista à revista Manchete, havia se manifestado a respeito da necessidade da decretação da anistia para pacificar os espíritos dos brasileiros. Depois do AI-5, o general foi expulso das Forças Armadas e do STM. Em seguida, filiou-se ao MDB. Esteve presente na fundação do primeiro CBA, no Rio de Janeiro. 
$\mathrm{Na}$ Assembleia Legislativa gaúcha, Bevilacqua (1978) se referiu a um "consenso nacional" que estaria pressionando o governo para a redemocratização. Esta redemocratização levaria o Brasil “à posse de si mesmo, à dignidade de um Estado de Direito e à Reconciliação de todos os brasileiros" (Bevilacqua, 1978). Para se chegar a isso, três medidas seriam necessárias: a revogação dos decretos conhecidos como Pacote de Abril, a revogação do AI-5 e a anistia política. Destes, o foco de concentração, neste artigo, é o último aspecto.

Para Bevilacqua (1978, p. 2), a anistia "deverá ser ampla, geral e irrestrita". Mais do que uma medida sentimental, ela foi defendida como uma "medida cerebral", de "alta sabedoria política", destinada a "desarmar os espíritos, a dissipar a sementeira de ódios que as injustiças e violências provocam, a premunir as vindictas futuras, a permitir e promover a Reconciliação [...]”. O general disse, ainda, que reconciliação é sinônimo de anistia e que esta é "o perdão, o esquecimento, o eterno silêncio". Até aqui, pode-se ver a proximidade entre o seu entendimento sobre anistia e aquele das militantes do MFPA acima apresentadas. $O$ general Peri Bevilacqua também partilhava da crença de que o Brasil possuía uma longa e positiva tradição de anistias e que seria necessário buscar na história brasileira os exemplos a serem seguidos naquele momento crucial pelo qual passava o país. As menções ao Duque de Caxias, patrono do Exército Nacional e grande pacificador, ocupam boa parte do tempo gasto para falar sobre a história das anistias brasileiras. Situações referentes à pacificação do Rio Grande do Sul, ao final da Guerra dos Farrapos, são enfatizadas, talvez para conquistar a simpatia da plateia a sua frente.

Apesar de Bevilacqua (1978) empregar a expressão anistia ampla, geral e irrestrita, que virá a ser a marca registrada dos CBAs, aos três adjetivos mencionados, o general acrescentou um quarto. A anistia, além de ampla, geral e irrestrita, deveria ser recíproca. Para ele,

\section{[...] os torturadores de presos politicos, por exemplo,} deverão ser abrangidos pela anistia, mesmo que as consequências do seu procedimento criminoso tenham sido a morte de suas vítimas. E os subversivos que, por motivos politicos, hajam cometido crimes semelhantes ou atentados contra a vida, em açôes ditas, geralmente, terroristas, também deverão, no interesse da paz social (Bevilacqua, 1978, p. 10).

Só sendo geral e recíproca, na compreensão de Bevilacqua (1978), a anistia poderia ser justa, desarmaria os espíritos e acabaria com a sementeira de ódios.

Passados mais de trinta anos, busca-se analisar esta fala e acentua-se o desafio de encontrar lógica - e justeza
- em uma proposição como essa. Como, no momento, não se propõe cruzar esse texto com outros do mesmo autor, talvez uma investigação sobre a coerência interna do discurso preparado para a palestra na Assembleia Legislativa dê algumas pistas. A primeira pista diz respeito à defesa da ideia de que as autoridades, às quais estavam subordinados os autores dos crimes da repressão, também deveriam ser anistiadas. Mesmo que essas autoridades tivessem errado - ao não cumprirem devidamente seu dever ou por serem cúmplices dos crimes de seus subordinados - deveriam ser anistiadas. Há, nessa postulação, uma insinuação de que a repressão fugiu ao controle dos níveis hierárquicos superiores. Se isso aconteceu, torna-se menos difícil defender as instituições como um todo. Não foram as Forças Armadas que cometeram crimes, mas alguns homens dentro delas.

Outra pista colhida no texto da palestra reforça o argumento da defesa das Forças Armadas e dos seus feitos por Bevilacqua (1978). Este general mencionou o caso de um militar que seria beneficiado pela anistia, o capitão Sérgio Ribeiro Miranda de Carvalho. Este capitão foi afastado da Aeronáutica por discordar de um plano criminoso para realização de atos terroristas no Rio de Janeiro, em 1968. Caso ele não tivesse se insurgido contra seus superiores, segundo Bevilacqua (1978, p. 11), "a Revolução ter-se-ia perdido, irremissivelmente desmoralizada, chafurdada em ignomínia, afogada num turbilhão de sangue de pessoas inocentes”. Pela lógica do general, mesmo que a Revolução não tenha se desmoralizado, neste momento, logo depois, ela foi golpeada pelo AI-5, "produto adulterino da Revolução de 31 de março de 1964, que se dizia restauradora da democracia” (Bavilacqua, 1978, p. 13). O AI-5, ainda segundo Bevilacqua (1978, p. 13), "comprometeu os ideais do Movimento de 31 de março de 1964, que não foi propriamente uma revolução e sim [...] uma antirrevolução, oposta pela consciência cívica do povo brasileiro, através de suas Forças Armadas, à maré montante da subversão [...]".

Com essas linhas, fica claro de onde Bevilacqua fala. Ele se coloca como um militar que, apesar de ter sido contrário à tentativa de golpe de 1961, compartilhava a crença de que o Brasil estava sendo contaminado pela subversão e que as Forças Armadas, respondendo a um apelo da Nação, tinham tomado o poder em 1964, visando a restaurar a democracia. No entanto, isso não se concretizou, porque o Movimento de 31 de março fora traído. O fruto foi o filho ou produto adulterino, o AI-5. Parece, então, que o casamento entre as Forças Armadas e os apelos da Nação não gerou uma família sólida. Houve traição e adultério. Sente-se, com isso, um lamento pelo rumo que as coisas tomaram. 
Ao mesmo tempo, é possível ler uma espécie de mea-culpa do general, por ter acreditado nos propósitos democratizantes e saneadores da "Revolução". Em certo ponto da palestra, ele afirmou que "será sempre preferível suportar um mau governo a fazer uma boa revolução" (Bevilacqua, 1978, p. 14).

\section{A anistia ampla e geral}

No mesmo mês em que Bevilacqua proferiu a palestra em Porto Alegre, Roberto Ribeiro Martins concluía a redação de Liberdade para os Brasileiros: anistia ontem e hoje, publicado, ainda naquele ano, pela Editora Civilização Brasileira. Em setembro, o livro foi lançado na Assembleia Legislativa do Rio Grande do Sul, ocasião em que o autor e o historiador Hélio Silva - que fez o prefácio para a obra - se dirigiram ao público gaúcho. Uma breve incursão em Liberdade para os brasileiros permitirá avançar no estudo das diferentes concepções que sustentaram a luta pela anistia. ${ }^{3}$

O livro é composto por duas partes: a primeira trata da história das anistias brasileiras, a partir das quais o autor tira algumas conclusões históricas; a segunda se refere à anistia que está sendo buscada no presente da escrita. Nesta parte, apresenta-se o surgimento da ideia de anistia após 1964, a diversidade dos beneficiários da anistia, o debate internacional recente e, ainda, os principais pontos do debate em curso. A redação da parte histórica, segundo o autor, foi prejudicada pela quase inexistência de bibliografia, à exceção da obra de Rui Barbosa, do final do século XIX. Ainda assim, utilizando fontes bibliográficas mais gerais sobre História do Brasil, livros de memória, anais do Congresso Nacional, imprensa e comentários jurídicos, o autor conseguiu reconstituir e contextualizar as anistias da história brasileira, do período colonial, às vésperas do golpe de 1964. Diferente do que se lê nos textos dos militantes da anistia acima mencionados, o livro de Martins trata mais da história das anistias brasileiras do que da tradição de anistias do Brasil. Isso porque, mais do que louvar essa pretensa tradição, o autor procura destacar as particularidades de cada situação histórica; as consequências de cada concessão; enfim, as demandas dos grupos que, em diferentes conjunturas, lutavam pela anistia. São apresentados, além disso, os textos das leis ou decretos de anistia e identificados os momentos em que a medida foi geral ou parcial. Destacam-se, ainda, as restrições que implementação. Outro aspecto que merece destaque é a

diferenciação entre as anistias concedidas pelo Executivo e pelo Congresso Nacional, o que mudou na História do Brasil de acordo com a correlação de forças entre os poderes em cada conjuntura, ou ainda, na redação de cada Constituição. Assim, fica-se sabendo que as Cartas de 1891, 1934 e 1946 atribuíam exclusivamente ao Congresso o poder de anistiar. Não foi o caso das Constituições de 1937 ou de 1967, esta reformada em 1969. Por esta última, apenas ao Presidente da República cabia a iniciativa de enviar projeto de anistia ao Congresso.

Entre as conclusões históricas a que Martins (1978) chega, vale destacar as seguintes: a anistia esteve presente em quase todos os momentos importantes da História do Brasil. Em alguns momentos, no entanto, ela esteve ausente e isto, para o autor, era resultado da extrema disparidade de forças entre rebelados e poder estabelecido. Antes de serem anistiados, os primeiros foram exterminados. Outra conclusão é que a "a anistia, por si só, não é suficiente" (Martins, 1978, p. 112). Ela precisa ser acompanhada de liberdade. Caso contrário, "a intolerância ressurgirá em pouco tempo" (Martins, 1978, p. 112). Outra conclusão remete à disparidade dos tipos de anistias concedidas, entre as quais destacam-se as que tiveram caráter geral, ou seja, que anistiaram todos os envolvidos em ações consideradas crimes políticos em determinado período. As anistias parciais são aquelas destinadas a uma ou a outra categoria: desertores da Força Expedicionária Brasileira, operários grevistas, estudantes, jornalistas etc. Algumas das anistias brasileiras não foram gerais. Foram "graduadas, parciais, restritivas e condicionais" (Martins, 1978, p. 113). Variadas situações políticas estiveram na origem de diferentes anistias:

\section{[...] às vezes, conquista de movimento revolucionário vitorioso, outras em decorrência de acordo entre as partes em luta; umas, consequência da mudança na si- tuação politica, outras, concessão do poder; umas vitória da pressão popular e democrática, outras instrumentos de repressão a movimentos rebeldes (Martins, 1978, p. 113).}

Esta última citação condensa um dos aspectos mais significativos da obra Liberdade para os brasileiros, que consegue romper com o discurso genérico da tradição de anistias e passa a apresentar a medida como resultado de correlação de forças entre os que estavam no poder e os que contra ele se rebelaram. O autor, assim, vai além da menção superficial às anistias do Brasil. Busca, pela

\footnotetext{
${ }_{3}^{3}$ Não foi possível encontrar informações sobre a formação e o engajamento político do autor. O fato de ele mencionar a presidente do núcleo do CBA do Rio de Janeiro, a advogada Eny Raimundo Moreira, nos agradecimentos, sugere que ele tinha relações com esse grupo.
} 
pesquisa histórica, compreender como, quando e por que aconteceram ou não anistias.

Embasado nessa análise circunstanciada das anistias brasileiras, o autor passa a refutar proposições que faziam parte do debate contemporâneo à escrita, as quais rechaçavam a necessidade de uma lei de anistia e apresentavam alternativas para a situação brasileira. Martins (1978) colocou-se contra medidas que eram restritas e paliativas, como: (i) a revogação do artigo 185 da Constituição (que tirava da Carta os poderes concedidos pelo AI-5 ao Presidente da República); (ii) a revisão ou revogação das punições; (iii) a revisão da Lei de Segurança Nacional; (iv) a anistia parcial; (v) a anistia recíproca; (vi) a anistia após a Constituinte etc.

$\mathrm{O}$ foco agora se concentra na refutação da anistia recíproca. Sobre isso, o autor diz que não há precedentes históricos e que "a reciprocidade é uma figura inexistente no Direito" (Martins, 1978, p. 177). Um dos comentários a respeito dos defensores da anistia recíproca parece se dirigir ao general Peri Bevilacqua:

\section{[...] é preciso ainda ressaltar que os que têm se pro- nunciado partidários de uma 'anistia recíproca' antes acrescentam 'ampla e irrestrita', situando-se entre aqueles que a entendem no essencial de forma correta. Estas pessoas certamente pensam que do ponto de vista tático a colocação poderia contribuir para um consenso entre governantes e governados em torno da anistia (Martins, 1978, p. 177).}

Realmente, na palestra de Bevilacqua (1978), na Assembleia Legislativa gaúcha, pode-se captar esta justificativa para a proposta de anistia recíproca. O general considerava que a anistia só viria se ela fosse recíproca, já que, em geral, a oposição do governo e dos militares à proposta era muito forte. Caso ambos os lados - revolucionários e contrarrevolucionários - fossem anistiados, as sementeiras do ódio poderiam ser destruídas. Ao mesmo tempo, a defesa da reciprocidade estava ligada à constatação de Bevilacqua (1978) de que existiria no Brasil uma exageração do perigo comunista. Por conta disso, a volta dos exilados, a soltura dos presos políticos, a reintegração de funcionários civis e militares, considerados subversivos ou comunistas, eram vistas com um grande perigo. Isso gerava muita resistência à anistia. Tal resistência poderia ser contornada, na visão do general, caso se propusesse uma medida de perdão e de esquecimento geral, para ambos os lados. Mesmo que tal proposta tenha parecido antipática para os defensores da anistia ampla, geral e irrestrita, ela foi vista como uma insinuação maldosa por setores da Forças Armadas. Martins (1978, p.178) apresenta, como exemplo disso, a fala do presidente do Superior Tribunal Militar
(STM), Almirante Hélio de Azevedo Leite, para quem falar em reciprocidade significaria pedir que "a Revolução prestasse conta de seus atos".

Dessa forma, o autor de Liberdade para os Brasileiros deixou clara sua oposição à anistia recíproca, defendendo que a anistia se referia "a direitos humanos desrespeitados" e que seria justo e natural que, no futuro, estas pessoas buscassem esclarecimentos sobre a violação de seus "mínimos direitos humanos" (Martins, 1978, p. 178). Com isso, pode-se concluir que Roberto Ribeiro Martins não concordava com uma anistia silêncio, uma anistia esquecimento. Mesmo que ele não discuta especificamente essa dimensão presente no debate sobre anistia, em um momento de sua análise histórica, o problema do silêncio é mencionado. Ao falar da anistia de 1945, decretada por Vargas, mencionou a avaliação do jornalista David Nasser, segundo o qual "os policiais brasileiros, autores de crimes contra a humanidade, mantêm-se em seus postos, impunes e felizes, quase todos bem instalados na vida" (Martins, 1978, p. 89). Segundo o mesmo jornalista, uma Comissão de Inquérito, formada na Câmara dos Deputados para apurar as monstruosidades cometidas durante o Estado Novo, vivia adiando seus trabalhos, o que levava a crer que estivesse interessada em silenciar os fatos. Martins (1978, p. 89) conclui que, realmente, a Comissão silenciou e, o que é mais grave, "na prática, todos esqueceram, sem, contudo, isso ter qualquer coisa a ver com o decreto da anistia". Ou seja, mesmo que o decreto não contivesse uma cláusula de reciprocidade - a qual pressuporia a necessidade de esquecimento do que ambas as partes fizeram -, a sociedade silenciou e os crimes não foram averiguados. Esta observação é muito forte, já que responsabiliza a sociedade pelo esquecimento, mais do que a lei.

Para Martins (1978), a anistia de 1945 não se referia, segundo a menção no seu texto à expressão "crimes conexos", a crimes cometidos pelos agentes do Estado, e sim a crimes comuns relacionados aos crimes políticos que tivessem sido julgados pelo Tribunal de Segurança Nacional. No caso da lei de anistia de 1979, a inclusão da expressão "crimes conexos" foi interpretada como significando uma anistia recíproca. Não é aqui o momento de investigar como surgiu e se desenvolveu, entre 1978 e 1979 , esta ligação entre os crimes conexos e a reciprocidade da anistia. Interessa apenas ressaltar que este foi o consenso presente nas avaliações a respeito da lei de 1979. Apenas recentemente essa interpretação começou a ser questionada. Um dos argumentos deste questionamento é de que a lei da anistia contrariou a própria Constituição em vigor - segundo a qual "os crimes dolosos, intencionais, contra a vida seriam julgados pelo Tribunal do Juri” (Selligmann-Silva, 2007, p. 3). Os torturadores, como servidores públicos, segundo essa lógica, agiam profissio- 
nalmente e não poderiam alegar motivações políticas para suas ações ou seus crimes.

Outro argumento contra a identificação entre crimes conexos e reciprocidade da anistia é o que aponta a tortura como crime contra a humanidade. Segundo Bicudo (2009, p. 3), pela Constituição de 1988,

[...] a tortura é considerada crime hediondo, insuscetivel de graça ou anistia, bem como imprescritivel a ação de grupos armados civis ou militares contra a ordem constitucional e o Estado democrático. Dessa forma, os crimes cometidos pelos agentes da Ditadura militar, civis ou militares, não cabem na Lei de Anistia e são imprescritiveis, quer dizer, os seus autores podem, a qualquer tempo, ser sujeitos à investigação e ulterior submissão ao poder judiciário.

\section{A anistia entre a memória e o esquecimento, ou sobre a vitória do esquecimento}

Após essa reflexão, volta-se a atenção aos laços entre anistia e esquecimento. Para a historiadora Heloísa Greco (2003, p. 403), que, antes de redigir uma tese sobre a luta dos CBAs pela anistia, foi militante da causa, "a dimensão trágica da anistia" foi a vitória da concepção de anistia como esquecimento. Três pontos centrais da luta dos CBAs não foram contemplados pela lei: (i) o reconhecimento das mortes e dos desaparecimentos; (ii) a responsabilização dos agentes do Estado pela tortura; e (iii) a não reciprocidade. Estas metas só seriam alcançadas, se a lei rompesse com a dimensão do esquecimento, trazendo à tona as atrocidades cometidas durante a $\mathrm{Di}^{-}$ tadura. A anistia, assim, teria um sentido de anamnesis, de reminiscência necessária à consecução da justiça como resgate da memória e direito à verdade, diferentemente da concepção que embasou o projeto governamental: a de anistia como amnésia.

O mais trágico, porém, é que a vitória da anistia esquecimento não se deu apenas pela maioria que o governo dispunha no Congresso, em agosto de 1979. A consolidação da amnésia foi resultado de posturas assumidas pela própria oposição ao Regime e pela sociedade como um todo, depois da aprovação da lei. Contribuíram, para isso, os discursos de militares, autoridades civis e da grande imprensa que diziam que o tema da tortura era intocável depois da anistia (considerada) recíproca. Quem tocasse em temas como esse, estaria sendo revanchista. O próprio movimento pela anistia teria sido um tanto culpado pela vitória do esquecimento, por difundir a ideia de que a sociedade como um todo tinha lutado contra a
Ditadura, quando, na verdade, o Regime teve um considerável apoio popular. Essa sociedade, segundo Greco (2003, p. 381), "se auto-anistia como maneira de mitigar a própria cumplicidade". Além disso, o esquecimento foi reforçado porque boa parte da sociedade não havia tido contato direto com o terror de Estado. Por outro lado, as manifestações públicas dos exilados que retornavam ao Brasil, a partir de setembro de 1979 , teriam enfocado mais as lacunas da experiência da oposição armada à Ditadura do que os méritos, a lógica e as condições da mesma. Começava a ser construída aí uma versão de que o romantismo e a inconsequência dos jovens tinham sido as marcas da oposição à Ditadura, especialmente durante os anos de chumbo.

Com esses e outros argumentos, a autora convence seus leitores da vitória da anistia esquecimento. Adentra, ainda, na legislação posterior à lei de 1979, centrada em questões administrativas, que contribuiu para que as demandas por anistia passassem a ser encaminhadas em nível individual, apagando as dimensões políticas da questão. Reconhece avanços inegáveis no processo de reconhecimento da responsabilidade do Estado nos casos de mortos e desaparecidos e no dever do Estado de reparar as vítimas da Ditadura. Lamenta, no entanto, o avanço nulo no esclarecimento e a responsabilização jurídica dos torturadores, além da despolitização da questão da anistia. Clama por uma reparação que é devida a toda a sociedade e não apenas aos requerentes individuais. Para ir adiante nesta discussão, seria necessário adentrar nas polêmicas a respeito da atuação do Ministério da Justiça e da Comissão de Anistia, tema que não poderá ser tratado aqui. A própria existência de polêmicas quanto aos encaminhamentos de reparações às vítimas da tortura é indício de que os confrontos entre memória e esquecimento - no que diz respeito à anistia e à Ditadura de modo geral - ainda têm lugar de destaque no debate político atual.

Finalizando, crê-se ser importante lembrar que as concepções de anistia aqui apresentadas devem ser compreendidas no tempo em que elas foram produzidas e difundidas. Não há como cobrar, por exemplo, que aqueles grupos de mulheres que alçaram a bandeira da anistia em 1975 tivessem em seu discurso uma radicalidade parecida com a que marcou o discurso dos CBAs, em 1978 e 1979. De 1975 ao final de 1978, o AI-5 ainda estava em vigor. No começo desse período, a censura à imprensa ainda estava ativa. A confiança na política da distensão era muito tênue, o que pode ser confirmado pelos assassinatos de Vladimir Herzog e Manuel Fiel Filho, entre 1975 e 1976, em São Paulo. A caça aos subversivos ainda animava importantes setores no poder. Por outro lado, até aqueles que, no governo Geisel, propunham o afrouxamento da tensão sobre a oposição, acabaram apelando para medidas como o fecha- 
mento do Congresso e a cassação de parlamentares. Assim, o terreno era ainda muito inseguro para propostas mais radicais de luta para a reconquista do Estado de Direito. Além disso, é preciso lembrar que, com o passar dos anos, novos protagonistas passaram a ocupar o espaço público: o movimento estudantil, o movimento contra a carestia, o movimento sindical etc. Novas companhias foram, então, se somando a(o)s lutadora(e)s da anistia. Com isso, outras preocupações passaram a figurar nas campanhas. As concepções de anistia continuaram se modificando: à luta pela anistia aos atingidos pelos atos de exceção, somou-se a luta pela anistia para todo o povo. Aos poucos - e ainda hoje -, a defesa da anistia passou a ser identificada como a defesa dos direitos humanos.

\section{Referências}

ABREU, A.A.; BELOCH, I.; LATTMAN-WELTMAN, F.; LAMARÃO, S.T. de N. 2001. Peri Bevilacqua. In: A.A. ABREU; I. BELOCH; F. LATTMAN-WELTMAN; S.T. de N. LAMARÃO, Dicionário Histórico Biográfico Brasileiro - Pós 1930. $2^{\text {a }}$ ed., Rio de Janeiro, Editora da Fundação Getúlio Vargas, vol. 1, p. 655-657.

BICUDO, H. 2009. Anistia e crimes contra a humanidade que não prescrevem. Com Ciência, Revista Eletrônica de Jornalismo Científico, n. 106. Disponível em: http://www.comciencia. $\mathrm{br} /$ comciencia/?section $=8 \&$ edicao $=43 \& \mathrm{xid}=525$, acessado em: 20/03/2009.

DEL PORTO, F.B. 2002. A luta pela anistia no regime militar: a constituição da sociedade civil no país e a construção da cidadania. Campinas, SP. Dissertação de mestrado. Universidade Estadual de Campinas, $145 \mathrm{p}$.

GRECO, H. 2003. Dimensôes fundacionais da luta pela anistia. Belo Horizonte, MG. Tese de doutorado. Universidade Federal de Minas Gerais, 559 p.

LINS E SILVA, E. 2001. Anistia. In: A.A. ABREU; I. BELOCH; F. LATTMAN-WELTMAN; S.T. de N. LAMARÃO, Dicionário
Histórico Biográfico Brasileiro - Pós 1930. 2a ed., Rio de Janeiro, Editora da Fundação Getúlio Vargas, vol. 1, p. 255-257.

PEDRO, J.M. 2006. Narrativas fundadoras do feminismo: poderes e conflitos (1970-1978). Revista Brasileira de História, 26(52):249-272.

RODEGHERO, C.S.; DIENSTMANN, G.; TRINDADE, T. 2009. Anistia ampla, geral e irrestrita: história de uma luta inconclusa. Porto Alegre, Assembleia Legislativa do Rio Grande do Sul. [no prelo].

SELLIGMANN-SILVA, M. 2007. Anistia e (in)justiça no Brasil: o dever da memória e a impunidade. Literatura e autoritarismo: memórias da repressão, 9(janeiro-junho). Disponível em: http:// coralx.ufsm.br/grpesqla/revista/num09/art_02.php, acessado em: $15 / 04 / 2009$

SOHIET, R.; ESTEVES, F.C. 2007. O Centro da Mulher Brasileira (CMB-RJ) e suas experiências nos anos 1970 e 1980. In: D.A. REIS FILHO; J. FERREIRA, As esquerdas no Brasil. Rio de Janeiro, Civilização Brasileira, vol. 3, p. 355-384.

\section{Fontes primárias}

BEVILACQUA, P. 1978. Anistia. Palestra proferida na Assembleia Legislativa do RS. Porto Alegre, 23 p. [mimeo].

CAUDURO, M. 1976a. Minuta de carta enviada ao deputado Alcides Franciscato (Arena-SP), 29 set.

CAUDURO, M. 1976b. Minuta de carta enviada ao deputado federal Aldo Fagundes (MDB-RS), 28 set.

CAUDURO, M. 1976c. Minuta da carta enviada a Justino Vasconcelos (OAB-RS), 11 ago.

MARTINS, R.R. 1978. Liberdade para os brasileiros: anistia ontem e hoje. Rio de Janeiro, Ed. Civilização Brasileira, 198 p.

MOVIMENTO FEMININO PELA ANISTIA-RS (MFPA-RS). 1978. Livro de Atas. Ata n ${ }^{\circ}$ 7, 20 jul.

ZERBINE, T. 1979. Anistia: a semente da liberdade. São Paulo, Gráfica das Escolas Profissionais Salesianas, 253 p.

Submetido em: 30/04/2009 Aceito em: 13/05/2009
Carla Simone Rodeghero

Universidade Federal do Rio Grande do Sul

Departamento de História

Av. Bento Gonçalves, 9500, Bloco 3, Prédio 43311, Sala 116

Agronomia, 91509-900, Porto Alegre, RS, Brasil. 